\title{
LIQUID-LIQUID EXTRACTION-SPECTROPHOTOMETRIC DETERMINATION OF MOLYBDENUM USING O-HYDROXYTHIOPHENOLS
}

\author{
Ali Z. Zalov, Kiril B. Gavazov*
}

Department of Analytical Chemistry, Azerbaijan State Pedagogical University, 34 Gadzhibekova St., Baku 1000, Azerbaijan

\section{zalov1966@mai.ru}

Department of General and Inorganic Chemistry, University of Plovdiv "Paisii Hilendarskii”, 24 Tsar Assen Str., 4000 Plovdiv, Bulgaria

* Corresponding Author: kgavazov@abv.bg

\begin{abstract}
27 liquid-liquid extraction-chromogenic systems containing Mo(VI), o-hydroxythiophenol derivative (HTPDs: 2-hydroxy-5chlorothiophenol (HCTP), 2-hydroxy-5-bromothiophenol (HBTP) or 2-hydroxy-5-iodothiophenol (HITP)\} and aromatic amine (AA) were studied. Aniline (An), N-methylaniline (mAn), N,N-dimethylaniline (dAn), o-toluidine (o-Tol), m-toluidine (m-Tol), p-toluidine ( $p$-Tol), 3,4-xylidine (o-Xyl), 2,4-xylidine ( $\mathrm{m}$-Xyl), and 2,5-xylidine ( $\mathrm{p}$-Xyl) were the examined AAs. Optimization experiments for molybdenum extraction-spectrophotometric determination were performed and the following parameters were found for each of the systems: organic solvent (opt), $\mathrm{pH}$ (opt), $\mathrm{C}_{\mathrm{HTPD}}$ (opt), $\mathrm{C}_{\mathrm{AA}}$ (opt), shaking time (opt), $\lambda$ (max) and $\varepsilon(\max )$. Under the optimum conditions, the molar ratio of the reacting Mo(V), HTPD and AA was 1:2:2 and the degrees of Mo extraction were $R \geq 98.4 \%$. Linear relationships involving the spectral characteristics of the extracted complexes $\left(\lambda_{\max }\right.$ or $\left.\varepsilon_{\max }\right)$ and some fundamental properties of the halogen substituent in the HTPD were discussed. The effect of foreign ions was examined and two sensitive, selective and precise procedures for extraction-spectrophotometric determination of molybdenum were proposed. The relative standard deviations for Mo content of $(3-5) \times 10^{-4}$ mass $\%$ were $4 \%$ (HCTP-An procedure) and 3\% (HBTP-An procedure).
\end{abstract}

\section{Indexing terms/Keywords}

Molybdenum(V); solvent extraction; ternary complex; soil analysis; plant analysis; linear relationship

\section{Academic Discipline And Sub-Disciplines}

Chemistry

\section{SUBJECT CLASSIFICATION}

Analytical chemistry; Inorganic Chemistry; General chemistry

\section{TYPE (METHOD/APPROACH)}

Types of research: experiments; Approach: quantitative research

\section{Council for Innovative Research}

\author{
Peer Review Research Publishing System
}

\section{Journal: Journal of Advances in Chemistry}

\author{
Vol.., No..




\section{INTRODUCTION}

Molybdenum has been recognized as an essential trace element for plants, animals and humans [1-3]. In plants, it has a key function in the fixation of the atmospheric nitrogen, while in humans, it is important for the activity of the enzymes xantine oxidase, sulphite oxidase, and aldehyde oxidase. It is known that molybdenum has a beneficial effect on patients with sulphite sensitivity and asthma. It has also been stated that it reduces the incidence of dental caries. On the other hand, molybdenum can be toxic at high concentrations [2-4]. In mammals, it increases the lability of blood pressure, disturbs the cholesterol transport and causes bone deformation. Effects of acute molybdenum toxicity include diarrhoea, anaemia and gout. Chronic occupational exposure has been associated with weakness, fatigue, lack of appetite, anorexia, joint pain and tremor [3].

Despite its relative rarity in the Earth's crust (estimated abundance in the range $0.05-40 \mathrm{mg} \mathrm{kg}^{-1}$ with a mean value of 1.5 $\mathrm{mg} \mathrm{kg}^{-1}$ ) [5,6], geochemical anomalies leading to molybdenum deficiencies in plants are not common $[7,8]$ and are mostly of concern for leguminous crops. Molybdenum fertilization is often based on visual deficiency symptoms and/or history of crop rotation [8]. However, in order to assess the need for fertilization and the molybdenum dosage it is preferable to use analytical methods $[5,6]$.

Recently, several techniques have been used for molybdenum determination: UV-Vis spectrophotometry, inductively coupled plasma mass spectrometry (ICP-MS), flame atomic absorption spectrophotometry (FAAS), electrothermal atomic absorption spectrometry (ETAAS), adsorptive anodic stripping voltammetry, and inductively coupled plasma optical emission spectrophotometry (ICP-OES) [9-15]. The methods involving spectrophotometry are rather popular due to their simplicity, inexpensive instrumentation and easy automation. In many cases, they are based on ion-association reaction between heavy organic cations and anionic complexes of $\mathrm{Mo}(\mathrm{V}, \mathrm{VI})$ with thiocyanate or organic reagents containing hydroxyl groups in ortho-position to each other [15-24].

Sulfur-containing analogues of the aforementioned catecholic reagents have been in our research interests for a long time because of their analytical potential and possibilities of obtaining new ternary complexes with desired properties [25-29]. In the present paper, we report results from liquid-liquid extraction-spectrophotometric experiments on 27 different systems, each of which containing $\mathrm{Mo}(\mathrm{VI})$, a o-hydroxythiophenol derivative (HTPD) \{2-hydroxy-5-chlorothiophenol (HCTP), 2hydroxy-5-bromothiophenol (HBTP), and 2-hydroxy-5-iodothiophenol (HITP)\}, and an aromatic amine (AA) \{aniline (An), $\mathrm{N}$-methylaniline (mAn), N,N-dimethylaniline (dAn), o-toluidine (o-Tol), m-toluidine ( $m$-Tol), p-toluidine (p-Tol), 3,4-xylidine (o-Xyl), 2,4-xylidine (m-Xyl), and 2,5-xylidine $(p-X y l)$. We propose new procedures for determining molybdenum in soils and plants, and show that linear relationships exist between the spectral characteristics of the ternary complexes (absorption maximum and molar absorptivity) and some fundamental properties of the halogen atom included in the HTPDs (atomic mass and electronegativity).

\section{EXPERIMENTAL}

\section{Reagents and apparatus}

A stock solution of $\mathrm{Mo}(\mathrm{VI})\left(1 \mathrm{dm}^{3}\right)$ was prepared by dissolving $1.8402 \mathrm{~g}$ of $\left(\mathrm{NH}_{4}\right)_{6} \mathrm{Mo}_{7} \mathrm{O}_{24} \cdot 4 \mathrm{H}_{2} \mathrm{O}($ Sigma-Aldrich, 99.98\%) in distilled water. The solution was standardized gravimetrically. Working solutions $\left(0.1 \mathrm{mg} \mathrm{cm}^{-3}\right)$ were prepared daily by appropriate dilution of the stock solution.

HTPDs were synthesized according to the procedure [30]; their purity was verified by paper chromatography and melting point determination. AAs were products of Sigma-Aldrich (98-99\% purity). Chloroform solutions $\left(0.01 \mathrm{~mol} \mathrm{dm}^{-3}\right)$ of HTPDs and $A A s$ were used.

A masking solution $\left(1 \mathrm{dm}^{3}\right)$, containing $75 \mathrm{~g}$ of citric acid and $150 \mathrm{~g}$ of ascorbic acid, was prepared weekly and stored in a refrigerator. A second masking solution was prepared from $\mathrm{KI}(\mathrm{W}=20 \%)$.

To create the optimum acidity, $0.1 \mathrm{~mol} \mathrm{dm}^{-3}$ solutions of $\mathrm{HCl}$ or $\mathrm{NaOH}$ were used.

The absorbance of the extracts was measured using a KFK-2 photocolorimeter (USSR) and a Camspec M508 spectrophotometer (UK), equipped with 5 and $10 \mathrm{~mm}$ path-length cells. $\mathrm{pH}$ of aqueous phase was measured using an I120.2 potentiometer with a glass electrode. Muffle furnace was used for dissolution of the samples.

\section{Procedure for determining the optimum conditions}

Aliquots of $\mathrm{Mo}(\mathrm{VI})$ solution, HTPD solution (up to $2.5 \mathrm{~cm}^{3}$ ) and AA solution (up to $2.5 \mathrm{~cm}^{3}$ ) were transferred in a $50 \mathrm{~cm}^{3}$ calibrated tube with ground-glass stopper. $\mathrm{pH}$ of the aqueous phase was adjusted in the interval 3.5-7.9 by adding a small amount of $\mathrm{HCl}$ or $\mathrm{NaOH}$ solution. The volume of the aqueous phase was increased with water to $20 \mathrm{~cm}^{3}$ and the volume of the organic phase was set to be $5 \mathrm{~cm}^{3}$. The tube was closed with the stopper and shaken for a fixed time (up to $15 \mathrm{~min}$ ). After separation of the layers, a portion of the organic extract was transferred into a cell and the absorbance was read against organic solvent or simultaneously prepared blank sample.

\section{Procedure for molybdenum determination}

An aliquot containing molybdenum (no more than $90 \mu \mathrm{g}$ when HTPD=HCTP or $85 \mu \mathrm{g}$ when HTPD=HBTP) was placed in a calibrated tube. Chloroform solutions of HTPD $\left(0.7 \mathrm{~cm}^{3}\right)$ and An $\left(0.7 \mathrm{~cm}^{3}\right)$ were added and the organic phase was adjusted to $5 \mathrm{~cm}^{3}$ with chloroform. The volume and $\mathrm{pH}$ of the aqueous phase were adjusted to $20 \mathrm{~cm}^{3}$ and $5.3-5.8$, respectively. The tube was closed with a stopper and after 10 minutes of shaking a portion of the organic extract was 
transferred through a filter paper into a cell. The absorbance was read at $\lambda_{\max }(535 \mathrm{~nm}$ when HTPD=HCTP or $530 \mathrm{~nm}$ when HTPD=HBTP) against a simultaneously prepared blank sample. The molybdenum content was found from a calibration graph.

\section{Soil sample preparation for analysis}

A soil sample $(15 \mathrm{~g})$ collected from depths of $15 \pm 5 \mathrm{~cm}$ was subjected to available molybdenum extraction procedure $[31,32]$ with an oxalate buffer of $\mathrm{pH}$ 3.3. Then the procedure [31] was followed: An aliquot of the obtained soil extract (50$100 \mathrm{~cm}^{3}$ ) was placed in a quartz beaker and evaporated to dryness on a hot plate. For dehydration of the residue and partial sublimation of the oxalates, the beaker was left on the plate for 30 more minutes. The beaker was transferred in a cold muffle furnace. The temperature was raised to $500^{\circ} \mathrm{C}$ and held for 1 hour. After cooling, $2 \mathrm{~cm}^{3}$ of perchloric acid were added for complete destruction of the organic matter. The content was heated to near dryness on a hot plate and the beaker was placed again in the muffle furnace. The temperature was raised to $500^{\circ} \mathrm{C}$ and held for $15-20$ minutes. The residue was cooled and then dissolved in $25 \mathrm{~cm}^{3}$ of $14 \%$ hydrochloric acid under heating. Masking solutions were added $\left(4 \mathrm{~cm}^{3}\right.$ of the citric acid - ascorbic acid solution and $2 \mathrm{~cm}^{3}$ of the $\mathrm{KI}$ solution) and the resulting solution was filtered into a $100-\mathrm{cm}^{3}$ separatory funnel. Aliquots of thus obtained filtrate were used to determine the molybdenum content.

\section{Plant sample preparation for analysis}

$10 \mathrm{~g}$ of the powdered plant material (seeds of pea) were soaked in $50 \mathrm{~cm}^{3}$ of $96 \%$ ethanol for $24 \mathrm{~h}$. The sample was dried and carefully carbonized in a quartz beaker on a hot plate. The beaker was placed into a cold muffle furnace and its temperature was slowly increased (at a rate of $100^{\circ} \mathrm{C}$ per hour) up to $450^{\circ} \mathrm{C}$. The sample was dry-ashed for $10-15 \mathrm{~h}$. The obtained gray ash was cooled and moistened with a few drops of nitric acid (1:1). Then the ash was heated to dryness on a water bath and placed into the muffle furnace. The temperature was raised to $300^{\circ} \mathrm{C}$ and held for 30 minutes. This cycle was repeated several times until white ash was obtained. Then, several drops of bidistilled water and $2 \mathrm{~cm}^{3}$ of perchloric acid were added. The beaker was heated on a hot plate until smoking ceased and transferred in a cold muffle furnace. The temperature was raised to $500{ }^{\circ} \mathrm{C}$ and held for 15 minutes. After cooling, $25 \mathrm{~cm}^{3}$ of $14 \%$ hydrochloric acid were added and the beaker was kept in a boiling water bath for 10-20 min. The obtained solution was quantitatively transferred to a volumetric flask of $50 \mathrm{~cm}^{3}$ [31]. Masking solutions were added $\left(4 \mathrm{~cm}^{3}\right.$ of the citric acid - ascorbic acid solution and $2 \mathrm{~cm}$ of the $\mathrm{KI}$ solution) and the flask was filled to the mark with bidistilled water.

\section{RESULTS AND DISCUSSION}

\section{Studies on the oxidation state of molybdenum}

It is known that HTPDs have reducing properties in acidic medium $[26,28,33]$. Previous investigations with $\mathrm{Mo}(\mathrm{VI})$ - $\mathrm{HCTP}$ and $\mathrm{Mo}(\mathrm{V})$-HCTP [26] suggested that only $\mathrm{Mo}(\mathrm{V})$ forms stable complexes with this reagent. To elucidate the oxidation state of molybdenum in the presence of other HTPDs (HBTP and HITP), we conducted two series of experiments. In the first series we used $\mathrm{Mo}(\mathrm{VI})$, while in the second series we used $\mathrm{Mo}(\mathrm{V})$ obtained by addition of a supplementary reducing agent $\left(\mathrm{SnCl}_{2}\right.$ or $\left.\mathrm{KI}\right)$. The comparison of the obtained spectra showed that $\lambda_{\max } \mathrm{Mo}(\mathrm{VI})-\mathrm{TPHHD}=\lambda_{\max } \mathrm{Mo}(\mathrm{V})$ - $\mathrm{TPHHD}$. This fact can be regarded as an indication $[26,34]$ that $\mathrm{Mo}(\mathrm{VI})$ is reduced to $\mathrm{Mo}(\mathrm{V})$ by the reagent itself during the process of complex formation.

\section{Charge of the complexes}

The charge of the Mo(V)-HTPD binary complexes was determined by electromigration and ion-exchange. Experiments on electromigration in a U-shaped tube and sorption on anion exchanger EDE-10P demonstrated the anionic nature of the complexes. Under the experimental conditions, these red binary complexes were insoluble in nonpolar organic solvents. However, when AAs were introduced the formation of electroneutral chloroform extractable ternary complexes was observed.

\section{Choice of organic solvent}

The following organic solvents were tested for the extraction of the complexes: chloroform, dichloroethane, carbon tetrachloride, benzene, toluene, diethyl ether and n-butanol. Chloroform was found to be the most effective in terms of degree of extraction $(R \%)$ and rapid equilibration. As can be seen from Table 1, chloroform provides $R \geq 98.4 \%$. At that, the nature of AA does not appreciably affect the extraction.

\section{Influence of $\mathbf{p H}$}

Figure 1 represents the influence of $\mathrm{pH}$ on the absorbance of the Mo(V)-HTPD-An extracts. The optimum pH ranges are wide enough to ensure stable and reproducible results without using buffer solutions. The course of all pH curves supports the assumption that only one complex is formed in each of the extraction systems. The optimum pH intervals are listed in Table 1. At higher $\mathrm{pH}$ values, the efficiency of the extraction is impaired, which relates to the lower degree of $A A$ protonation. At lower pH values, the extraction is also impaired most probably due to decrease of the concentration of the anionic HTPDs forms. 
Table 1. Characteristics of the Mo(V)-HTPD-AA-water-chloroform extraction-chromogenic systems

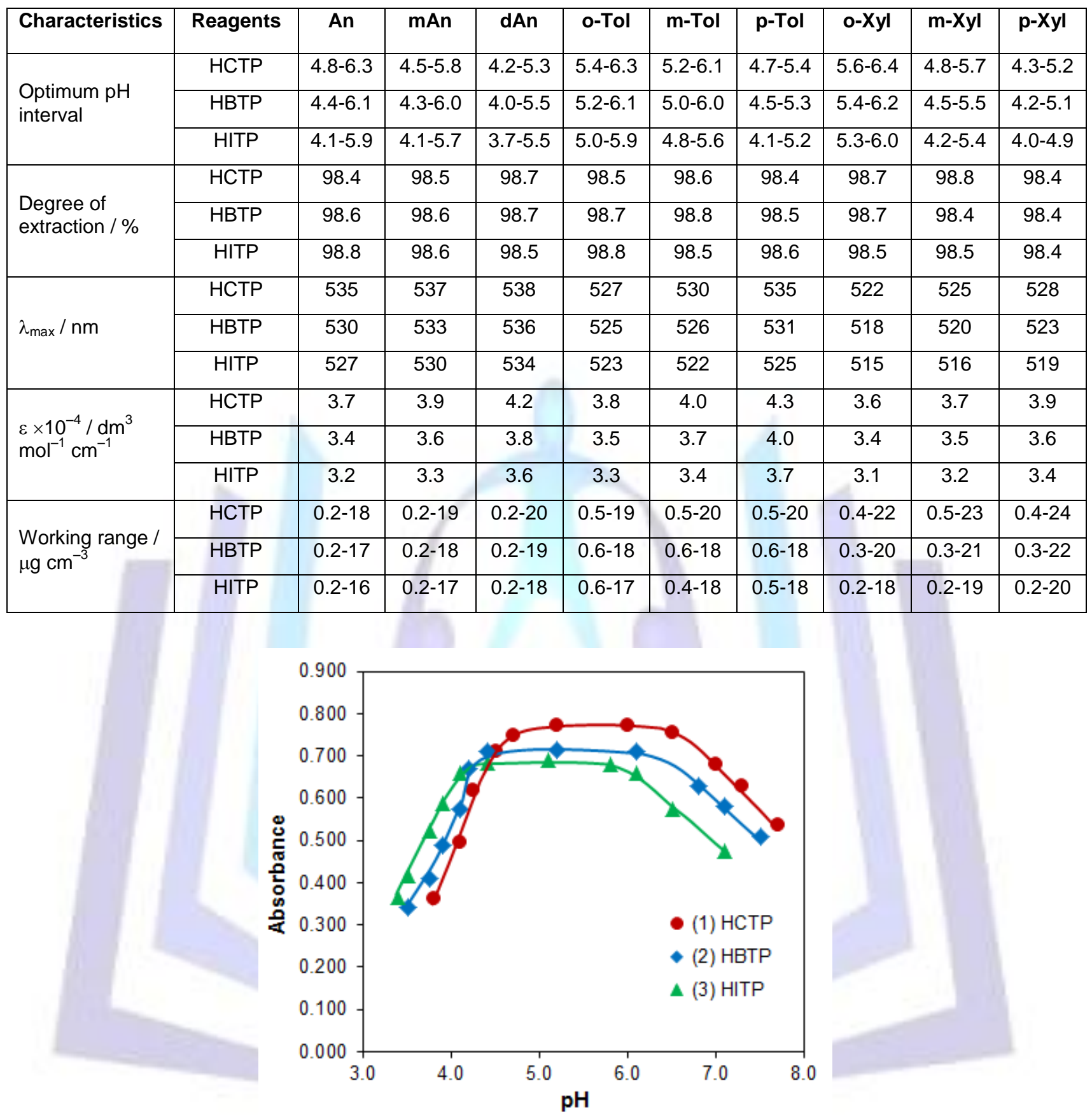

Fig 1: Absorbance of the ternary Mo(V)-HTPD-An complexes vs. pH of the aqueous phase. (1) HTPD=HCTP; (2) HTPD=HBTP; (3) HTPD=HITP. $C_{M o}(V)=4.16 \times 10^{-5} \mathrm{~mol} \mathrm{dm}^{-3}, C_{H T P D}=C_{A n}=1.4 \times 10^{-3} \mathrm{~mol} \mathrm{dm}^{-3}, \ell=0.5 \mathrm{~cm}$

\section{Absorption maxima, reagents concentrations, molar absorptivities and effect of time}

The absorption maxima $\left(\lambda_{\max }\right)$ of the ternary Mo(V)-HTPD-AA complexes lie in the range of $516-538 \mathrm{~nm}(\mathrm{Table} 1)$. All colour reactions are very contrast since the initial solutions are colourless $\left(\lambda_{\max }\right.$ HTPDs $\left.=275-280 \mathrm{~nm}\right)$. Complete extraction is achieved at HTPD and AA concentrations not lower than (1.3-1.5) $\times 10^{-3} \mathrm{~mol} \mathrm{dm}^{-3}$ and $(1.2-1.5) \times 10^{-3} \mathrm{~mol} \mathrm{dm}^{-3}$, respectively. $\mathrm{Mo}(\mathrm{V})$ concentration ranges in which the Beer's law is obeyed are listed in Table 1. The calculated molar absorptivities $\left(\varepsilon_{\max }\right)$ belong to the interval $(3.1-4.3) \times 10^{4} \mathrm{dm}^{3} \mathrm{~mol}^{-1} \mathrm{~cm}^{-1}$. Colour develops almost immediately after the reagents addition. The absorbance of the extracts is stable for at least 48 hours. The optimum shaking time is $10 \mathrm{~min}$.

\section{Stoichiometry of the ternary complexes}

The molar ratios of the components of the ternary complexes were established by the equilibrium shift method [35] and the method of Asmus [36]. The results show a complex composition of 1:2:2 (Mo(V):HTPD:AA). Using the Nazarenko's 
method [37], we found that the molybdenum complexation form is $\mathrm{MoO}(\mathrm{OH})^{2+}$. Hence, the complexes can be regarded as ion associates between doubly charged anionic chelates $\left[\mathrm{Mo}^{\mathrm{V}} \mathrm{O}(\mathrm{OH})\left(\mathrm{HTPD}^{2-}\right)_{2}\right]^{2-}$ and two protonated $A A$ species: $\left(\mathrm{AAH}^{+}\right)_{2}\left[\mathrm{MoO}(\mathrm{OH})(\mathrm{HTPD})_{2}\right]$.

\section{Effect of foreign ions and masking reagents}

The influence of foreign ions and reagents on the extraction-spectrophotometric determination of molybdenum with $\mathrm{HCTP}+\mathrm{An}$ and HBTP+An was examined in details. It was found that great excesses of alkali, alkali earth, and rare earth cations do not interfere with determination. The same was valid for anions, such as $\mathrm{F}^{-}, \mathrm{Cl}^{-}, \mathrm{Br}^{-}, \mathrm{SO}_{3}{ }^{2-}, \mathrm{SO}_{4}{ }^{2-}$ and $\mathrm{C}_{2} \mathrm{O}_{4}{ }^{2-}$. Serious interferences were observed from small amounts (less than $200 \mu \mathrm{g}$ ) of $\mathrm{Fe}(\mathrm{III}), \mathrm{Ti}(\mathrm{IV}), \mathrm{Cu}(\mathrm{II}), \mathrm{Nb}(\mathrm{V}), \mathrm{Ta}(\mathrm{V}), \mathrm{Hg}(\mathrm{II})$ and $\mathrm{W}(\mathrm{VI})$. The interfering influence of these ions can be eliminated by using various masking agents (Table 2$)$. For the sake of convenience, we used only two masking solutions in our further analytical work: 1) ascorbic acid + citric acid solution; and 2) KI solution.

Table 2. Influence of foreign ions on the determination of molybdenum $(50 \mu \mathrm{g})$ with HCTP ${ }^{\mathrm{a}}$ and An

\begin{tabular}{|c|c|c|c|c|}
\hline Foreign ion (FI) & Fl-to-Mo ratio & Masking agent & Mo found / $\mu \mathrm{g}$ & $\mathbf{R S D}^{\mathbf{b}} / \%$ \\
\hline $\mathrm{Al}(\mathrm{III})$ & 100 & - & 50.0 & 1.5 \\
\hline $\mathrm{Bi}(\mathrm{III})$ & 40 & - & 49.5 & 4.5 \\
\hline $\mathrm{Co}(\mathrm{II})$ & 55 & - & 50.4 & 4.2 \\
\hline $\mathrm{Cr}(\mathrm{VI})$ & 70 & - & 49.6 & 2.3 \\
\hline $\mathrm{Cu}(\mathrm{II})$ & 25 & $\mathrm{KI}$ & 50.0 & 2.1 \\
\hline $\mathrm{Fe}(\mathrm{III})$ & 50 & Ascorbic acid & 50.4 & 4.2 \\
\hline $\mathrm{Hg}(\mathrm{II})$ & 35 & $\mathrm{Na}_{2} \mathrm{~S}_{2} \mathrm{O}_{3}$ & 49.8 & 2.4 \\
\hline $\mathrm{Nb}(\mathrm{V})$ & 45 & Oxalic acid & 50.2 & 1.5 \\
\hline $\mathrm{Ni}(\mathrm{II})$ & 50 & Citric acid & 50.0 & 1.5 \\
\hline $\mathrm{Ta}(\mathrm{V})$ & 45 & Ascorbic acid & 49.7 & 2.3 \\
\hline $\mathrm{Ti}(\mathrm{IV})$ & 20 & Ascorbic acid & 49.6 & 2.3 \\
\hline $\mathrm{V}(\mathrm{IV})$ & 40 & - & 50.0 & 1.5 \\
\hline $\mathrm{W}(\mathrm{VI})$ & 40 & Citric acid & 50.3 & 4.2 \\
\hline $\mathrm{Zr}(\mathrm{IV})$ & 70 & - & 49.6 & 2.3 \\
\hline
\end{tabular}

${ }^{\text {a }}$ Statistically undistinguished results were obtained by using HBTP at the mentioned FI-to-Mo ratios

${ }^{\mathrm{b}}$ Relative standard deviation based on three determinations

\section{Calibration graphs, analytical characteristics and application}

Table 3 summarizes the calibration characteristics obtained with HCTP+An and HBTP+An. The procedures with these reagents were applied to the determination of molybdenum in samples of soil and pea. The accuracy of the results was checked by two independent methods. The results are listed in Table 4.

Table 3. Analytical characteristics for the Mo-HCTP-An and Mo-HBTP-An extraction-chromogenic systems

\begin{tabular}{|c|c|c|}
\hline Parameter & Mo-HCTP-An & Mo-HBTP-An \\
\hline Linear calibration range $/ \mu \mathrm{g} \mathrm{cm}^{-3}$ & up to 4.5 & up to 4.3 \\
\hline Slope \pm Standard deviation $/{\mathrm{A} \mu \mathrm{g}^{-1} \mathrm{~cm}^{3}}^{3}$ & $0.383 \pm 0.004$ & $0.351 \pm 0.03$ \\
\hline Intercept \pm Standard deviation / A & $0.007 \pm 0.011$ & $0.007 \pm 0.008$ \\
\hline Correlation coefficient ( 9 standards used) & 0.9994 & 0.9997 \\
\hline Limit of detection (LOD) / $\mathrm{ng} \mathrm{cm}^{-3}$ & $15^{\mathrm{a}}$ & $12^{\mathrm{a}}$ \\
\hline Limit of quantification (LOQ) / $\mathrm{ng} \mathrm{cm}^{-3}$ & $50^{a}$ & $40^{a}$ \\
\hline Sandell's sensitivity / $\mathrm{ng} \mathrm{cm}^{-2}$ & 2.61 & 2.85 \\
\hline
\end{tabular}

${ }^{a}$ Defined as $3 \sigma / a(L O D)$ or $10 \sigma / a(L O Q)$, where a is the slope of the calibration plot 
Table 4. Analytical characteristics for the Mo-HCTP-An and Mo-HBTP-An extraction-chromogenic systems

\begin{tabular}{|c|c|c|c|c|c|}
\hline \multicolumn{2}{|l|}{ Method } & \multicolumn{2}{|c|}{ Molybdenum content in soil } & \multicolumn{2}{|c|}{ Molybdenum content in pea } \\
\hline & & $\times 10^{4} / \%$ & RSD / \% & $\times 10^{4} / \%$ & RSD / \% \\
\hline \multirow{2}{*}{$\begin{array}{l}\text { Present } \\
\text { methods }\end{array}$} & HCTP-An method & 2.93 & 4.0 & 4.95 & 4.0 \\
\hline & HBTP-An method & 2.86 & 3.0 & 5.03 & 3.0 \\
\hline \multicolumn{2}{|c|}{ Dithiol method [31] } & 2.97 & 5.0 & 5.02 & 5.0 \\
\hline \multicolumn{2}{|c|}{ Thiocyanate method [31] } & 2.96 & 5.0 & 5.03 & 5.0 \\
\hline
\end{tabular}

\section{Some linear relationships involving the spectral characteristics of the complexes}

The nature of the substituents and the molecular mass of the associating ions are important factors in the chemistry of ionassociation $[20,38]$. Linear relationships have been described between the molecular mass of a particular class of cationic ion-association reagents [20,38] and some parameters, such as constant of association [38], temperature of decomposition [39], constant of extraction [40], and molar absorptivity [40].

The HTPDs used in this work provided an excellent opportunity to examine the influence of the halogen substituent $(\mathrm{Cl}, \mathrm{Br}$, I) on the spectral characteristics of the ternary complexes (molar absorptivity $\varepsilon_{\max }$ and absorption maximum $\lambda_{\max }$ ). The results showed that straight lines can be obtained by plotting the atomic mass of the halogen atom ( $\left.A_{\text {Hal }}\right)$ vs. $\lambda_{\text {max }}$ (Figure 2) or $\varepsilon_{\max }$ (Figure 3). The experimental data plotted in coordinates $\lambda_{\max }-\chi_{\mathrm{Hal}}$ and $\varepsilon-\chi_{\mathrm{Hal}}$ (where $\chi_{\mathrm{Hal}}$ is the Pauling electronegativity of the halogen atom) also fit linear equations (Table 5) (the squared correlation coefficients $R^{2}$ are in the range of $0.9347-1.000)$. The differences in the slopes $\left(a_{i}\right)$ of the straight-lines $\lambda_{\max }=a_{1} \times A_{H a l}+b_{1}$ and $\lambda_{\max }=a_{2} \times \chi H_{a l}+b_{2}$ can $b e$ attributed to the different nature of the AAs used. However, the slopes were relatively constant for the straight lines $\varepsilon_{\max }=a_{3} \times A_{H a l}+b_{3}$ and $\varepsilon_{\max }=a_{4} \times \chi_{\mathrm{Hal}}+\mathrm{b}_{4}: \mathrm{a}_{3}=-0.0060 \pm 0.0005$ and $\mathrm{a}_{4}=1.08 \pm 0.09$. This fact can be used for simple prediction of molar absorptivities of still uninvestigated ternary complexes (e.g. Mo-HTPD-AA complexes where AA is 2,3-xylidine, 2,6xylidine or 3,5-xylidine). For this purpose, only one of the ternary complexes of a given AA (Mo-HCTP-AA, Mo-HBTP-AA or Mo-HITP-AA) must be experimentally examined.

Table 5 shows that the straight-line equations with participation of $\lambda_{\max }$ are characterised by relatively constant ordinate cuts $b_{i}\left(b_{1}=534 \pm 4\right.$ and $\left.b_{2}=485 \pm 12\right)$. This information can be used for predicting the absorption maxima of new ternary complexes after a single experimental step as outlined above.

Table 5. Equations and squared correlation coefficients $\left(R^{2}\right)$ describing the linear relationships between the atomic mass $\left(A_{\mathrm{Hal}}\right)$ or Pauling electronegativity $\left(\chi_{\mathrm{Hal}}\right)$ of the halogen atom in the HTPD and the spectral characteristics of the ternary complexes $\left(\lambda_{\max }\right.$ and $\left.\varepsilon_{\max }\right)$

\begin{tabular}{|c|c|c|c|c|}
\hline AA & $\lambda_{\max }=f\left(A_{\text {Hal }}\right)$ & $\varepsilon_{\max } \times 10^{-4}=f\left(A_{\text {Hal }}\right)$ & $\lambda_{\max }=f\left(\chi_{\text {Hal }}\right)$ & $\varepsilon_{\max } \times 10^{-4}=f\left(\chi_{\text {Hal }}\right)$ \\
\hline An & $\begin{array}{l}y=-0.0873 x+537.71 \\
R^{2}=0.9748\end{array}$ & $\begin{array}{l}y=-0.0055 x+3.8739 \\
R^{2}=0.9829\end{array}$ & $\begin{array}{l}y=15.526 x+485.23 \\
R^{2}=0.9347\end{array}$ & $\begin{array}{l}y=0.9737 x+0.5837 \\
R^{2}=0.9481\end{array}$ \\
\hline mAn & $\begin{array}{l}y=-0.0764 x+539.5 \\
R^{2}=0.9904\end{array}$ & $\begin{array}{l}y=-0.0066 x+4.1297 \\
R^{2}=0.9997\end{array}$ & $\begin{array}{l}y=13.684 x+493.28 \\
R^{2}=0.9616\end{array}$ & $\begin{array}{l}y=1.1842+0.1342 \\
R^{2}=0.9868\end{array}$ \\
\hline $\mathrm{dAn}$ & $\begin{array}{l}y=-0.0437 x+539.53 \\
R^{2}=0.9997\end{array}$ & $\begin{array}{l}y=-0.0065 x+4.3947 \\
R^{2}=0.9581\end{array}$ & $\begin{array}{l}y=7.8947 x+512.89 \\
R^{2}=0.9868\end{array}$ & $\begin{array}{l}y=1.1579 x+0.4779 \\
R^{2}=0.9098\end{array}$ \\
\hline o-Tol & $\begin{array}{l}y=-0.0437 x+528.53 \\
R^{2}=0.9997\end{array}$ & $\begin{array}{l}y=-0.0055 x+3.9739 \\
R^{2}=0.9829\end{array}$ & $\begin{array}{l}y=7.8947 x+501.89 \\
R^{2}=0.9868\end{array}$ & $\begin{array}{l}y=0.9737 x+0.6837 \\
R^{2}=0.9481\end{array}$ \\
\hline m-Tol & $\begin{array}{l}y=-0.0875 x+533.06 \\
R^{2}=0.9997\end{array}$ & $\begin{array}{l}y=-0.0066 x+4.2297 \\
R^{2}=0.9997\end{array}$ & $\begin{array}{l}y=15.789 x+479.79 \\
R^{2}=0.9868\end{array}$ & $\begin{array}{l}y=1.1842 x+0.2342 \\
R^{2}=0.9868\end{array}$ \\
\hline p-Tol & $\begin{array}{l}y=-0.1095 x+539.18 \\
R^{2}=0.9903\end{array}$ & $\begin{array}{l}y=-0.0066 x+4.5297 \\
R^{2}=0.9997\end{array}$ & $\begin{array}{l}y=20 x+471.8 \\
R^{2}=1.000\end{array}$ & $\begin{array}{l}y=1.1842 x+0.5342 \\
R^{2}=0.9868\end{array}$ \\
\hline $0-X y l$ & $\begin{array}{l}y=-0.07645 x+524.5 \\
R^{2}=0.9904\end{array}$ & $\begin{array}{l}y=-0.0055 x+3.8089 \\
R^{2}=0.9903\end{array}$ & $\begin{array}{l}y=13.684 x+478.28 \\
R^{2}=0.9616\end{array}$ & $\begin{array}{l}y=1.000 x+0.44 \\
R^{2}=1.000\end{array}$ \\
\hline$m-X y l$ & $\begin{array}{l}y=-0.0983 x+528.27 \\
R^{2}=0.9936\end{array}$ & $\begin{array}{l}y=-0.0055 x+3.9089 \\
R^{2}=0.9903\end{array}$ & $\begin{array}{l}y=17.632 x+468.73 \\
R^{2}=0.9683\end{array}$ & $\begin{array}{l}y=1.000 x+0.54 \\
R^{2}=1.000\end{array}$ \\
\hline$p-X y l$ & $\begin{array}{l}y=-0.0983 x+531.27 \\
R^{2}=0.9936\end{array}$ & $\begin{array}{l}y=-0.0055 x+4.0739 \\
R^{2}=0.9829\end{array}$ & $\begin{array}{l}y=17.632 x+471.73 \\
R^{2}=0.9683\end{array}$ & $\begin{array}{l}y=0.9737 x+0.7837 \\
R^{2}=0.9481\end{array}$ \\
\hline
\end{tabular}




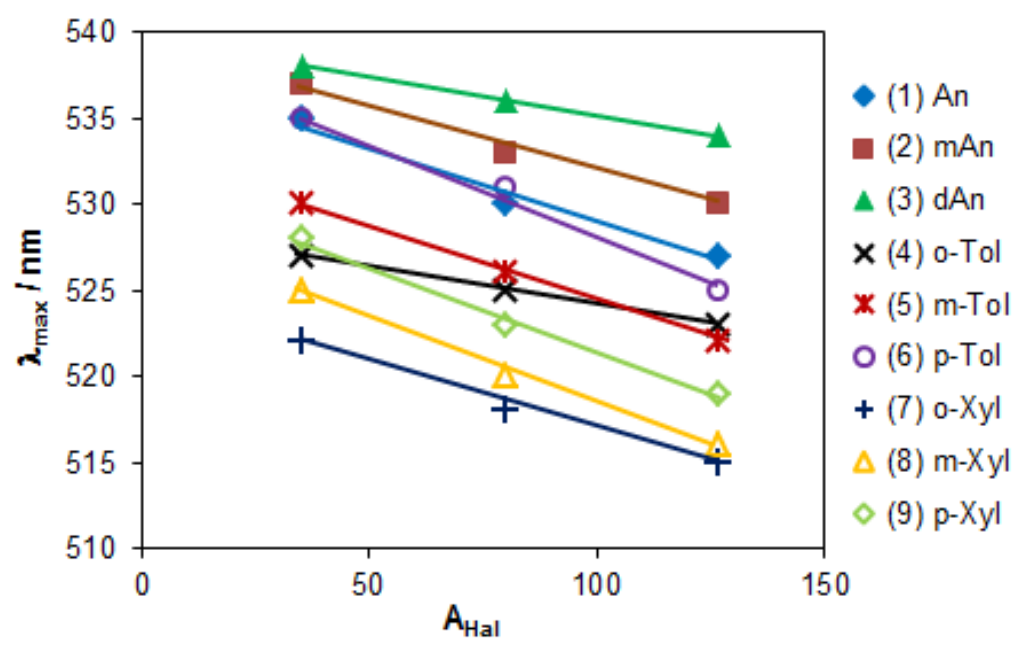

Fig 2: Straight lines obtained by plotting the absorption maxima of the ternary complexes $\left(\lambda_{\max }\right)$ vs. the atomic mass of the halogen in HTPDs $\left(A_{\mathrm{Hal}}\right)$. The corresponding linear equations are included in Table 5.

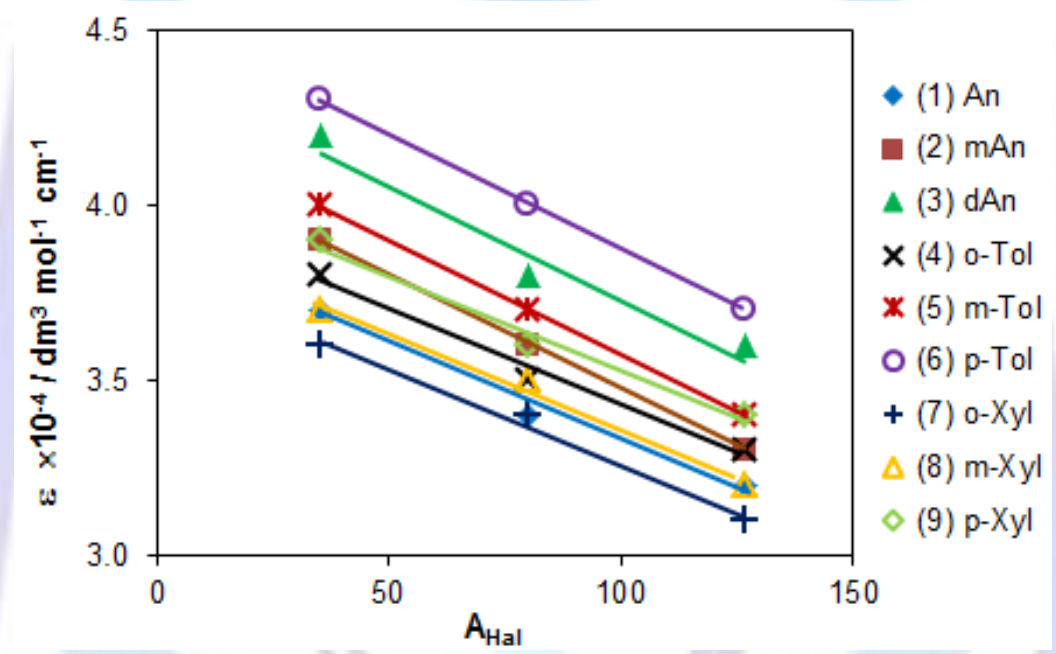

Fig 3: Straight lines obtained by plotting the molar absorptivity coefficients $(\varepsilon)$ vs. the atomic mass of the halogen in HTPDs $\left(A_{\mathrm{Hal}}\right)$. The corresponding linear equations are included in Table 5

\section{CONCLUSIONS}

Molybdenum(VI) forms well chloroform-extractable ternary complexes with HTPDs and AAs which can be used for liquidliquid extraction-spectrophotometric determination of molybdenum. The complexes have a composition of 1:2:2 (Mo:HTPD:AA) and can be regarded as ion associates between doubly charged anionic chelates of $\mathrm{Mo}(\mathrm{V})$ and protonated AA species: $\left(\mathrm{AAH}^{+}\right)_{2}\left[\mathrm{MoO}(\mathrm{OH})(\mathrm{HTPD})_{2}\right]$. The collected information about the spectral characteristics (absorption maximum $\lambda_{\max }$ and molar absorptivity $\varepsilon_{\max }$ ) of the complexes makes it possible to conclude that linear relationships exist between some fundamental properties of the halogen substituent in the HTPD (atomic mass $A_{\text {Hal }}$ and electronegativity $\chi_{\mathrm{Hal}}$ ) and $\lambda_{\max }$ or $\varepsilon_{\max }$ : (i) The higher the atomic mass, the lower $\lambda_{\max }$ and $\varepsilon_{\max }$; (ii) The higher the electronegativity $\chi_{\mathrm{Hal}}$, the higher the $\lambda_{\max }$ and $\varepsilon_{\max }$. The established constancy of the slopes or ordinate cuts of the obtained straight-line equations can facilitate the prediction of the mentioned spectral characteristics of new complexes of the same class.

\section{REFERENCES}

[1] Gupta U. C. (Ed.). 1997. Molybdenum in agriculture. Cambridge University Press, Cambridge.

[2] Anke, M., Seifert, M., Arnhold, W., Anke, S., and Schäfer, U. 2010. The biological and toxicological importance of molybdenum in the environment and in the nutrition of plants, animals and man. Acta aliment. 39(1), 12-26.

[3] Smedley, P. L., Cooper, D. M., Ander, E. L., Milne, C. J., and Lapworth, D. J. 2014. Occurrence of molybdenum in British surface water and groundwater: Distributions, controls and implications for water supply. Appl. Geochem. 40(0), 144-154.

[4] Momčilović, B. 1999. A case report of acute human molybdenum toxicity from a dietary molybdenum supplement-a new member of the "lucor metallicum" family. Arhiv za higijenu rada i toksikologiju 50(3), 289-297. 
[5] Das, A. K., Chakraborty, R., Cervera, M. L., and de la Guardia, M. 2007. A review on molybdenum determination in solid geological samples. Talanta 71(3), 987-1000.

[6] Kabata-Pendias, A. 2011. Trace elements in soils and plants (4th ed.). CRC press, Boca Raton. pp. 190-198.

[7] Kaiser, B. N., Gridley, K. L., Brady, J. N., Phillips, T., and Tyerman, S. D. (2005). The role of molybdenum in agricultural plant production. Ann. Bot. 96(5), 745-754.

[8] Gupta, U. C. and Hettiarachchi, G. M. 2007. Boron, Molybdenum, and Selenium. In Soil sampling and methods of analysis (2nd edition), M. R. Carter, E. G. Gregorich (Eds.) Boca Raton, p. 99.

[9] Kostova, D. 2011. Triphenyltetrazolium chloride as a new analytical reagent for molybdenum(VI): Application to plant analysis. J. Anal. Chem. 66(4), 384-388.

[10] Deng, P., Fei, J., Zhang, J., and Feng, Y. 2011. Determination of molybdenum by adsorptive anodic stripping voltammetry of molybdenum-alizarin violet complex at an acetylene black paste electrode. Food Chem. 124(3), 1231-1237.

[11] Khan, N., Jeong, I. S., Hwang, I. M., Kim, J. S., Choi, S. H., Nho, E. Y., Choi, J. Y., Kwak, B.- M., Ahn, J.- H., Yoon, T. and Kim, K. S. 2013. Method validation for simultaneous determination of chromium, molybdenum and selenium in infant formulas by ICP-OES and ICP-MS. Food Chem. 141(4), 3566-3570.

[12] Gürkan, R., Aksoy, Ü., Ulusoy, H. İ., and Akçay, M. 2013. Determination of low levels of molybdenum (VI) in food samples and beverages by cloud point extraction coupled with flame atomic absorption spectrometry. J. Food Compos. Anal. 32(1), 74-82.

[13] Mansouri, A. I., Afzali, D., and Ganjavi, F. 2013. Dispersive liquid-liquid microextraction of trace amounts of molybdenum prior to electro-thermal atomic absorption spectrometry determination. Int. J. Environ. Anal. Chem. 94(3), 247-254.

[14] Bazán, C., Gil, R., Smichowski, P., and Pacheco, P. 2014. Multivariate optimization of a solid phase extraction system employing I-tyrosine immobilized on carbon nanotubes applied to molybdenum analysis by inductively coupled plasma optical emission spectrometry with ultrasound nebulization. Microchem. J. 117, 40-45.

[15] Dass, R., Kapoor, J. K., and Gambhir, S. 2014. Spectrophotometric determination of molybdenum using surfactantmediated liquid--liquid extraction. Turk. J. Chem. 38(2), 328-337.

[16] Filik, H., Tütem, E., and Apak, R. 2004. Use of the molybdenum-thiocyanate-rhodamine 6G ternary complex for spectrophotometric molybdenum determination without extraction. Anal. Chim. Acta 505(1), 77-82.

[17] Dimitrov, A., Lekova, V., Gavazov, K., and Boyanov, B. 2005. Investigation of the extraction equilibrium of ionassociation complexes of molybdenum( $\mathrm{VI})$ with some polyphenols and thiazolyl blue. Extraction-spectrophotometric determination of molybdenum. Cent. Eur. J. Chem. 3(4), 747-755.

[18] Pyrzynska, K. 2007. Determination of molybdenum in environmental samples. Anal. Chim. Acta 590(1), 40-48.

[19] Dimitrov, A., Lekova, V., Gavazov, K., and Boyanov, B. 2007. Ternary complex of molybdenum(VI) with 4nitrocatechol and tetrazolium blue chloride and its application to extraction-spectrophotometric analysis of ferrous metallurgy products. J. Anal. Chem., 62(2), 122-125.

[20] Gavazov, K. B., Dimitrov, A. N., and Lekova, V. D. 2007. The use of tetrazolium salts in inorganic analysis. Russ. Chem. Rev. 76(2), 169-179.

[21] Kamburova, M., and Kostova, D. 2008. Tetrazolium violet - a new spectrophotometric reagent for molybdenum determination. Chemija 19(2), 13-18.

[22] Shrivas, K., Agrawal, K., and Harmukh, N. 2009. Trace level determination of molybdenum in environmental and biological samples using surfactant-mediated liquid-liquid extraction. J. Hazard. Mat. 161(1), 325-329.

[23] Abdessalam, S., Nabieva, A. M., Nabiev, M., and Hamada, B. 2009. Extraction-spectrophotometric method of determining molybdenum by dibenzo-18-crown-6. Azerbaijan J. Chem. 4, 158-162.

[24] Abdessalam, S., Ramazanova, G. G., Gahramanova, Z. O., Shabanov, A. L., and Nabiev, M. 2010. Spectrophotometric determination of $\mathrm{Mo}(\mathrm{VI})$ and $\mathrm{Co}(\mathrm{II})$ with simultaneous presence of crown ether (6-hydroxydibenzo-19-crown-6) in differemt drug forms. Kimya Problemleri 4, 668-673.

[25] Verdizade, N., Amrakhov, T. I., Kuliev, K. A., and Zalov, A. Z. 1997. 2-Hydroxy-5-chlorothiophenol (HCTP) as new analytical reagent for determination of V(V), Mo and W. Zh. Anal. Khim. 52(10), 1042-1046.

[26] Verdizade, N. A., Zalov, A. Z., Kuliev, K. A., Amrakhov, T. A., and Samedova, V. M. 2000. Extraction-photometric determination of molybdenum as a mixed-ligand complex with 2-hydroxy-5-chlorothiophenol and diphenylguanidine. J. Anal. Chem. 55(4), 331-334.

[27] Zalov, A., Verdizade, N. A., and Abaskulieva, U. B. 2012. Extraction-photometric determination of titanium(IV) with thiophenol hydroxyhalogen derivatives and aminophenols. Izv. Vyssh. Uchebn. Zaved. Ser. Khim. Khim. Tekhnol. 55(10), 23-29. 
[28] Zalov, A. Z., and Verdizade, N. A. 2013. Extraction-spectrophotometry determination of tungsten with 2-hydroxy-5chlorothiophenol and hydrophobic amines. J. Anal. Chem. 68(3), 212-217.

[29] Zalov, A. Z., and Gavazov, K. B. 2014. Extractive spectrophotometric determination of nickel with 2-hydroxy-5iodothiophenol and diphenylguanidine. Chem. J. 4(5), 20-25.

[30] Kuliev, A. M., Aliev, S. R., Mamedov, F. N., \& Movsumzade, M. 1976. Synthesis of aminomethyl derivatives of $2-$ hydroxy-5-tert-alkylthiophenols and their cleavage by thiols. Zh. Org. Khim. 12(2), 426-431.

[31] Mineev, V. G. (Ed.). 2001. Praktikum po agrokhimii (2 ${ }^{\text {-nd }}$ edition). Izd. Mosk. Gos. Univ., Moscow.

[32] Grigg, J. L. 1953. Determination of the available molybdenum of soils. New Zealand J. Sci. Tech. 34, 405-414.

[33] A. Z. Zalov, K. B. Gavazov, "Kompleksoobrazuvane i ekstraktiya na volfram s 2-hidroksi-5-bromotiofenol i aminofenoli”, Nauch. Tr. Plovdiv Univ. Khim., 2014, in press.

[34] Sommer, L., and Bartusek, M. 1966. Complexation of phenolic hydroxyl and its analytical consequences. Folia Fac. Sci. Nat. UJEP Brno Chem. 7(5), 46-63.

[35] Bulatov, M. I., and Kalinkin, I. P. 1986. Prakticheskoe rukovodstvo po fotokolorimetricheskim i spektrofotometricheskim metodam analiza. Khimiya, Leningrad.

[36] Asmus, E. 1960. Eine neue Methode zur Ermittlung der Zusammensetzung schwacher Komplexe. Fresenius' J. Anal. Chem. 178(2), 104-116.

[37] Nazarenko, V. A., and Biryuk, E. A. 1967. A study of the chemistry of reactions of multivalent element ions with organic reagents. Zh. Anal. Khim., 22(1), 57-64.

[38] Alexandrov, A., Simeonova, Z., and Kamburova, M. 1990. A relationship between association constants and the molecular mass of tetrazolium ion association complexes. Bulg. Chem. Commun. 23(4), 542-544.

[39] Gavazov, K., Lekova, V., Boyanov, B., and Dimitrov, A. 2009. Some tetrazolium salts and their ion-association complexes with the molybdenum(VI) - 4-nitrocatechol anionic chelate. DTA and TGA study. J. Therm. Anal. Cal. 96(1), 249-254.

[40] Gavazov, K. B., Stefanova, T. S., and Toncheva, G. K. 2014. Extraction-spectrophotometric studies on the complex formation of iron(III) with 4-(2-thiazolylazo)resorcinol and tetrazolium salts. J. Advanc. Chem. 10(3), 2491-2501. 